\title{
Improvement of variational-gradient method in dynamical systems of automated control for integro-differential models
}

\author{
Mashkov O. A. ${ }^{1}$, Sobchuk V. V. ${ }^{2}$, Barabash O. V. ${ }^{3}$, Dakhno N. B. ${ }^{3}$, Shevchenko H. V. ${ }^{3}$, \\ Maisak T. V. ${ }^{4}$ \\ ${ }^{1}$ State Ecological Academy of Postgraduate Education and Management, \\ 35, build. 2 Vasylia Lypkivskoho Str., 03035, Kyiv, Ukraine \\ ${ }^{2}$ Lesya Ukrainka East European National University, \\ 9 Potapova Str., 43000, Lutsk, Ukraine \\ ${ }^{3}$ State University of Telecommunications, \\ 7 Solomyanska str., 03110, Kyiv, Ukraine \\ ${ }^{4}$ Kyiv National Economic University named after Vadym Hetman, \\ 54/1 Peremohy Ave., Kyiv, 03057, Ukraine
}

(Received 15 May 2019; Revised 11 July 2019; Accepted 11 July 2019)

\begin{abstract}
The dynamical systems given by integro-differentiation models with $K$-symmetric $K$-positive-definite operator are considered. The variational-gradient method was applied to those models. The analysis showed that the implementation of this method does not require knowledge of the operator spectrum, in addition, it has a better convergence rate and is more resistant to disturbances than gradient methods. The theorem is proved in this paper, which allows us to draw conclusions about the effectiveness of the application of the variational-gradient method for the research of control problems. Investigation of an integro-differential model with a $K$-positive-definite $K$-symmetric operator using the variational-gradient method will increase the efficiency of information processing in the processes of control and research of dynamic systems. Application of the variationalgradient method to the control tasks will allow expanding the range of tasks under consideration. It is noted that the development of modern technologies entails an increase in the complexity of control objects, an increase in the quality requirements and the accuracy of control due to the increase in the cost of control error. This makes to be essential further development and improvement of methods that solve the problems of optimal control, for example, unmanned aerial vehicles. As the model example, the application of the variational-gradient method to the models of automated control systems for unmanned aerial vehicles is considered.
\end{abstract}

Keywords: automated control, variational-gradient method, dynamic systems, integrodifferential model, optimization of control.

2000 MSC: $34 \mathrm{~K} 28$

UDC: 517.977

DOI: $10.23939 / \mathrm{mmc} 2019.02 .344$

\section{Introduction}

The development of modern simulation techniques has created the prerequisites for the creation and research of highly effective systems, which are usually focused on digital algorithms for processing information, using modern microprocessors, neurocomputers, processors with fuzzy logic and other modern technological advances.

In modern simulation of continuous processes, the representation of dynamical systems in the state space is increasingly used. The description of dynamic systems is extremely diverse: it can be implemented using differential equations, discrete mappings, graph theory, the theory of Markov chains, etc. The choice of one of the methods describes a particular type of mathematical model of the corresponding dynamic system [1-4]. 
The paper assumes that the model is described using an integro-differential equation. This allows knowing the initial state to predict the future state of the dynamic system. The description of dynamic processes and systems using the differential equations makes it easy to carry out their digital modeling applying approximate methods and design universal algorithms for information processing in order to optimally evaluate the parameters of systems and processes. The optimal estimations are necessary for organization of control in systems of automatic control of modern models [5,6], and in information measuring systems for obtaining reliable data on measured physical quantities, for predicting behavior of investigated phenomena and systems, and increasing the failure-resistance of information processing [7-9].

The construction and implementation of the system of differential equations has become one of the most effective tools for modeling complex dynamic systems $[9,10]$. The complexity of modern models makes the apparatus of approximate computations virtually indispensable in this situation. Thanks to the development of numerical methods and the growth of computing power of modern technology, it was possible to take into account not only the most significant characteristics but also secondary factors in the models, which, in turn, has led to an increase in the accuracy of the models.

The most commonly used methods are variational, projection, gradient, difference. However, the size and complexity of modern models require huge resource costs for their implementation. These models include: an electromechanical tracking system for reproducing the angle of rotation; temperature stabilization system in the space orbital station compartment, digital air traffic control system, etc. [11-13].

In connection with this methods that are the synthesis of variational and gradient methods were recently developed. The obtained methods have a better convergence rate and are more resistant to disturbances than gradient methods. This allows you to reduce the estimated costs, which in turn saves time and memory to implement the model in practice. Such methods include the variational-gradient method [14-17].

\section{The problem statement}

We consider the application of the variational-gradient method to dynamic systems of automated control, which are described by integro-differential models with $K$-positive-definite $K$-symmetric operators.

Let the dynamic model be described by the boundary value problem:

$$
\begin{aligned}
& A u(t)=u^{(m)}(t)+c_{1}(t) u^{(m-1)}(t)+\ldots+c_{m}(t) u(t)+\sum_{j=0}^{m} \int_{a}^{b} H_{j}(t, \xi) u^{(j)}(\xi) d \xi=f(t), \quad t \in[a, b], \\
& U_{l}(u)=\sum_{j=0}^{m-1}\left(\alpha_{l j} u^{(j)}(a)+\beta_{l j} u^{(j)}(b)\right)=\sigma_{l}, \quad l=\overline{0, m-1}
\end{aligned}
$$

where $\alpha_{l j}, \beta_{l j}, \sigma_{l}$ and $0 \leqslant l, j \leqslant m-1$ are known values, and $c_{i} \in C([a, b]), i=\overline{i, m}$.

Operator $A: D(A) \rightarrow H$ is defined on a set $D(A)=\left\{u: u^{(m)} \in L_{2}[a, b], U_{l}=\sigma_{l}, l=\overline{0, m-1}\right\}$. Let operator $A$ is linear $K$-positive-definite and $K$-symmetric [18], so there is an operator $K: D(K) \rightarrow$ $L_{2}[a, b]$, that is as follows:

$$
\begin{aligned}
K u(t) & =u^{(n)}(t)+a_{1}(t) u^{(n-1)}(t)+\ldots+a_{n}(t) u(t)+\sum_{j=0}^{n} \int_{a}^{b} D_{j}(t, \xi) u^{(j)}(\xi) d \xi, \quad t \in[a, b], \\
U_{l}(u) & =\sigma_{l}, \quad l=\overline{0, m-1} .
\end{aligned}
$$

Mathematical Modeling and Computing, Vol. 6, No. 2, pp. 344-357 (2019) 
In addition, the following conditions are met:

$$
\begin{aligned}
\exists \alpha, \beta>0: & \int_{a}^{b}(A u)(t)(K u)(t) d t \geqslant \alpha \int_{a}^{b} u^{2}(t) d t, \quad \forall u \in D(A), \\
& \int_{a}^{b}(K u)^{2}(t) d t \leqslant \beta \int_{a}^{b}(A u)(t)(K u)(t) d t, \quad \forall u \in D(A), \\
& \int_{a}^{b}(A u)(t)(K v)(t) d t=\int_{a}^{b}(K u)(t)(A v)(t) d t, \quad \forall u, v \in D(A) .
\end{aligned}
$$

Assume that there is an operator $B: D(B) \rightarrow L_{2}[a, b]-D(B)=D(A)$ :

$$
\begin{aligned}
& B u(t)=u^{(m)}(t)+d_{1}(t) u^{(m-1)}(t)+\ldots+d_{m}(t) u(t)+\sum_{j=0}^{m} \int_{a}^{b} G_{j}(t, \xi) u^{(j)}(\xi) d \xi=g(t), \quad t \in[a, b], \\
& U_{l}(u)=\sigma_{l}, \quad l=\overline{0, m-1}
\end{aligned}
$$

That is linear $K$-positive-definite and $K$-symmetricand for (6), (7) it's easy to find solution $\forall g \in$ $L_{2}[a, b]$.

Let the relation is held:

$$
\begin{aligned}
\exists \gamma, \delta>0: 0<\gamma \leqslant \delta & <\infty, \forall u \in D(A), \\
& \gamma \int_{a}^{b}(B u)(t)(K u)(t) d t \leqslant \int_{a}^{b}(A u)(t)(K u)(t) d t \leqslant \delta \int_{a}^{b}(B u)(t)(K u)(t) d t .
\end{aligned}
$$

Then the investigation of the integro-differential model (1), (2) is equivalent to finding the minimum of a quadratic functional:

$$
F(u)=\int_{a}^{b}(A u)(t)(K u)(t) d t-2 \int_{a}^{b} f(t)(K u)(t) d t .
$$

Thus, in the execution of (3)-(8), the dynamic model (1), (2) has a unique generalized solution [18], which we shall finding from the condition of the minimum of a quadratic functional (9).

\section{Variational gradient method for the investigation of integro-differential control models}

We consider the integro-differential model (1), (2). Let $\left\{\varphi_{i}: i \geqslant 1\right\} \subset D(A)$ is a sytem linearly independent elements and $H_{0}$ is a subspace created by $\left\{\varphi_{i}: i \geqslant 1\right\}$. Let $u_{0} \in\left\{u: u^{(m)} \in L_{2}[a, b], U_{l}=\right.$ $\left.\sigma_{l}, l=\overline{0, m-1}\right\}$ is an arbitrary initial approximation, and we assume that the $(k-1)$-st approximation is found. Then we will look for the $k$-th according to the scheme:

$$
u_{k}(t)=x_{k}(t)+\sum_{i=1}^{n} \varphi_{i}(t) a_{i}^{k}, \quad t \in[a, b],
$$

here $x_{k}$ is determined from equality

$$
\begin{aligned}
B x_{k}(t) & =B u_{k-1}(t)+\tau_{k} r_{k}(t), \quad t \in[a, b], \\
U_{l}(u) & =\sigma_{l}, \quad l=\overline{0, m-1}, \quad k \geqslant 1,
\end{aligned}
$$

here $\tau_{k}$ is some unknown parameter, $r_{k}=f(t)-\left(A u_{k-1}\right)(t)$ is residual.

Mathematical Modeling and Computing, Vol. 6, No. 2, pp. 344-357 (2019) 
Unknown parameters $\tau_{k}$ and $a_{i}^{k}$ we seek from the condition of a quadratic functional (9) minimum. Since it is easy to find a solution for the problem (6), (7), there exists a Green's function [19] for the problem:

$$
\left(B R_{k}\right)(t)=r_{k}(t), \quad t \in[a, b], \quad U_{l}(u)=0, \quad l=\overline{0, m-1}, \quad k \geqslant 1 .
$$

So,

$$
R_{k}(t)=\int_{a}^{b} G(t, \xi) r_{k}(\xi) d \xi
$$

and the variational-gradient method (10)-(12) is as follows:

$$
u_{k}(t)=u_{k-1}(t)+\tau_{k} R_{k}(t)+\sum_{i=0}^{n} \varphi_{i}(t) a_{i}^{k}, \quad t \in[a, b] .
$$

From the condition of the functional (9) minimum, after transformations, taking into account (10)(15), we obtain a system of linear algebraic equations for the determination of unknown parameters $\tau_{k}$ and $a_{i}^{k}$ :

$$
\begin{aligned}
& \tau_{k} \int_{a}^{b}\left(A R_{k}\right)(t)\left(K R_{k}\right)(t) d t+\sum_{i=1}^{n} a_{i}^{k} \int_{a}^{b}\left(A R_{k}\right)(t)\left(K \varphi_{i}\right)(t) d t=\int_{a}^{b} r_{k}(t)\left(K R_{k}\right)(t) d t \\
& \tau_{k} \int_{a}^{b}\left(A R_{k}\right)(t)\left(K \varphi_{i}\right)(t) d t+\sum_{j=1}^{n} a_{j}^{k} \int_{a}^{b}\left(A \varphi_{j}\right)(t)\left(K \varphi_{i}\right)(t) d t=\int_{a}^{b} r_{k}(t)\left(K \varphi_{i}\right)(t) d t, \quad i=\overline{1, n}
\end{aligned}
$$

As operator $A$ is linear $K$-positive-definite and $K$-symmetric, then the system of algebraic equations (16), (17) has a unique solution for unknown $\tau_{k}$ and $a_{i}^{k}$.

From

$$
r_{k+1}(t)=f(t)-A u_{k}(t)=f(t)-A\left(u_{k-1}(t)+\tau_{k}\left(B^{-1} r_{k}\right)(t)+w_{k}(t)\right)=r_{k}(t)-\tau_{k}\left(A R_{k}\right)(t)-A w_{k}(t)
$$

and from (17) it follows that

$$
\int_{a}^{b} r_{k}(t)\left(K \varphi_{i}\right)(t) d t=0, \quad k \geqslant 2, \quad i \geqslant 1, \quad t \in[a, b]
$$

An amendment $w_{k}$ we will find in a form:

$$
w_{k}(t)=\sum_{i=1}^{n}\left(b_{i}^{k}-\tau_{k} c_{i}^{k}\right) \varphi_{i}(t)
$$

Then approximation (10) will take the form:

$$
u_{k}(t)=u_{k-1}(t)+\tau_{k} R_{k}(t)+\sum_{i=1}^{n}\left(b_{i}^{k}-\tau_{k} c_{i}^{k}\right) \varphi_{i}(t),
$$

Where parameters $b_{i}^{k}$ and $c_{i}^{k}$ are determined from systems:

$$
\begin{aligned}
& \sum_{i=0}^{n} b_{i}^{k} \int_{a}^{b}\left(A \varphi_{j}\right)(t)\left(K \varphi_{i}\right)(t) d t=\int_{a}^{b} r_{k}(t)\left(K \varphi_{j}\right)(t) d t, \quad j=\overline{1, n} \\
& \sum_{i=0}^{n} c_{i}^{k} \int_{a}^{b}\left(A \varphi_{j}\right)(t)\left(K \varphi_{i}\right)(t) d t=\int_{a}^{b}\left(A R_{k}\right)(t)\left(K \varphi_{j}\right)(t) d t, \quad j=\overline{1, n}
\end{aligned}
$$


After the transformations to determine the parameter $\tau_{k}$ an equation (16) will look like:

$\tau_{k} \int_{a}^{b}\left(A R_{k}\right)(t)\left(\left(K R_{k}\right)(t)-\sum_{i=1}^{n} c_{i}^{k}\left(K \varphi_{i}\right)(t)\right) d t=\int_{a}^{b}\left(K R_{k}\right)(t)\left(r_{k}(t)-\sum_{i=1}^{n} b_{i}^{k}\left(A \varphi_{i}\right)(t)\right) d t$.

Note, that if $k=1$ the system of equations (21) will have only zero solution. If to demand from the initial approximation $u_{0}$ to satisfy the condition:

$$
\int_{a}^{b} r_{1}(t)\left(K \varphi_{i}\right)(t) d t=0, \quad \forall i \geqslant 1
$$

than the system of algebraic equations (21) will have only trivial solution after performing the first iteration.

From the formula

$$
\int_{a}^{b}\left(K R_{k}\right)(t)\left(A x_{k}\right)(t) d t=\int_{a}^{b} r_{k}(t)\left(K y_{k}\right)(t) d t
$$

it follows that an equation (23) can be reduced to more convenient form to determine the unknown parameter $\tau_{k}$ :

$$
\tau_{k} \int_{a}^{b}\left(A R_{k}\right)(t)\left(\left(K R_{k}\right)(t)-\sum_{i=1}^{n} c_{i}^{k}\left(K \varphi_{i}\right)(t)\right) d t=\int_{a}^{b} r_{k}(t)\left(\left(K R_{k}\right)(t)-\sum_{i=1}^{n} c_{i}^{k}\left(K \varphi_{i}\right)(t)\right) d t .
$$

\section{Substantiation of the variational-gradient method convergence}

Theorem 1. When the conditions (5)-(8) are fulfilled, the variational gradient method (10)-(17) converges to the solution of the dynamic model (1), (2) and the rate of convergence is characterized by estimates:

$$
\begin{aligned}
& \left\|u^{*}-u_{k}\right\|_{B} \leqslant \sqrt{\frac{\eta}{\gamma}} q^{k-1}\left\|u^{*}-u_{1}\right\|_{B}, \quad k \geqslant 2, \\
& \left\|u^{*}-u_{k}\right\|_{B} \leqslant \sqrt{\frac{1}{\gamma \sigma}}\left\|B^{-1}\left(f-A u_{k}\right)\right\|_{B}, \quad k \geqslant 2,
\end{aligned}
$$

where $q=\frac{\eta-\sigma}{\eta+\sigma} ; \gamma \leqslant \sigma \leqslant \eta \leqslant \delta$.

Proof. On the set of operator definition area, we define a new scalar product [20]:

$$
[u, v]=(B u, K v), \quad u, v \in D(B) .
$$

For this scalar product and set $D(B)$, all axioms of the Hilbert space will be fulfilled, so they can be considered as a valid Hilbert space. Consider the closure of the set $D(B)$ in metric (28) and we will call it the energy space $H_{B}$. Linear set $D(B)$ is dense in the energy space $H_{B}$. Denote the element's norm $u$ in the space $H_{B}$ as $\|u\|_{B}$, so that

$$
\|u\|_{B}^{2}=[u, u], \quad u \in D(B) .
$$

Bisides that

$$
\begin{gathered}
G=B^{-1} A, \\
g=B^{-1} f .
\end{gathered}
$$


And let's consider an equation:

$$
G u=g .
$$

The linear operator $G$ is symmetric, positive-definite and bounded in $H_{B}$. It followes from (30) and transformations:

$$
\begin{aligned}
{[G u, v] } & =\left[B^{-1} A u, v\right]=(A u, K v)=(K u, A v)=(A v, K u) \\
& =\left(B B^{-1} A v, K u\right)=\left[B^{-1} A v, u\right]=\left[u, B^{-1} A v\right]=[u, G v] .
\end{aligned}
$$

And inequality (8) takes the form:

$$
\gamma\|u\|_{B}^{2} \leqslant[G u, u] \leqslant \delta\|u\|_{B}^{2}, \quad u \in H_{B} .
$$

As operator $G$ is symmetric positive-definite and bounded in $H_{B}$, an equation (32) has a unique generalized solution and solving equation (32) is equivalent to finding a minimum of a quadratic functional:

$$
F(u)=[G u, u]-2[g, u] .
$$

Consider the notation (30), (31) and perform certain transformations, then the variational gradient method (10)-(17) will take the form:

$$
u_{k}=u_{k-1}+\tau_{k} v_{k}+w_{k}, \quad w_{k} \in H_{0} \subset H_{B},
$$

here $v_{k}=g-G u_{k-1}$ is the residual, and the system of linear equations (16), (17), for definition $\tau_{k}$ and $w_{k}$ is equivalent to the ratios:

$$
\begin{aligned}
& {\left[G u_{k}, v_{k}\right]=\left[g, v_{k}\right],} \\
& {\left[v_{k}-\tau_{k} G v_{k}-G w_{k}, v\right]=0, \quad \forall v \in H_{0} .}
\end{aligned}
$$

Thus, the research of the dynamic model (1) by the variational-gradient method (10)-(17) in the space $H$ is equivalent to research the model (30) by the method (36)-(38) in the energy space $H_{B}$. From (24) it follows that

$$
\left[v_{k}, v\right]=0, \quad \forall v \in H_{0}, \quad k \geqslant 2 .
$$

Really, $\left[v_{k}, v\right]=\left[g-G u_{k-1}, v\right]=\left(B g-B G u_{k-1}, K v\right)=\left(f-A u_{k-1}, K v\right)=0, \forall v \in H_{0}, k \geqslant 2$.

So the system (38) with $k \geqslant 2$ will be as:

$$
\left[\tau_{k} G v_{k}+G w_{k}, v\right]=0, \quad v \in H_{0}
$$

As linear operator $G$ is symmetric positive-definite and bounded in $H_{B}$, then there is self-adjoint positive-definite operator $S: H_{B} \rightarrow H_{B}$ such that:

$$
G=S^{2}
$$

Let operators $P$ and $\hat{P}$ are the orthogonal projection operators [21] of the space $H_{B}$ into the subspace $H_{0}$ and $\hat{H}=S H_{0}$ respectively, and denote the projection operators:

$$
Q=I-P, \quad \hat{Q}=I-\hat{P},
$$

where $I$ is identity operator in $H_{B}$. Note that system (39) and (40) is equivalent to:

$$
\begin{aligned}
P\left(g-G u_{k-1}\right) & =0, \quad k \geqslant 2, \\
P\left(\tau_{k} G v_{k}+G w_{k}\right) & =0, \quad k \geqslant 2 .
\end{aligned}
$$


From the definition of residual $v_{k}$ it follows that:

$$
v_{k}=g-G u_{k-1}=G\left(u^{*}-u_{k-1}\right),
$$

where $u^{*} \in H_{B}$ is a generalized solution of (32).

According to (41) and (45) equations (43) and (44) are equivalent to relations:

$$
\begin{aligned}
\hat{P} S\left(u^{*}-u_{k-1}\right) & =0, \quad k \geqslant 2, \\
\tau_{k} \hat{P} S v_{k}+\hat{P} S w_{k} & =0, \quad k \geqslant 2 .
\end{aligned}
$$

It comes from (43) and transformations:

$$
\begin{aligned}
P\left(g-G u_{k-1}\right) & =P G\left(u^{*}-u_{k-1}\right)=P S S\left(u^{*}-u_{k-1}\right) \\
& =\hat{P} S\left(u^{*}-u_{k-1}\right)=0, \quad k \geqslant 2, \quad \forall u \in H_{B} .
\end{aligned}
$$

Similarly from (44) we have:

$$
P G\left(\tau_{k} v_{k}+w_{k}\right)=P S S\left(\tau_{k} v_{k}+w_{k}\right)=\hat{P} S\left(\tau_{k} v_{k}+w_{k}\right), \quad k \geqslant 2, \quad \forall u \in H_{B} .
$$

For operator $\hat{P}$, it follows that

$$
\hat{P} S w_{k}=S w_{k}, \quad w_{k} \in H_{0}, \quad k \geqslant 2 .
$$

And relationship (47) looks like:

$$
S w_{k}=-\tau_{k} \hat{P} S v_{k}, \quad k \geqslant 2
$$

Let's introduce an operator

$$
W=\hat{Q} G \hat{Q} .
$$

Linear operator $W$ reflects $H_{B}$ onto the subspace $\hat{H}^{\perp}$. It's symmetric so an inequality holds:

$$
\begin{gathered}
\sigma\|u\|_{B}^{2} \leqslant[W u, u] \leqslant \eta\|u\|_{B}^{2}, \quad \forall u \in H_{B}, \\
\gamma \leqslant \sigma \leqslant \eta \leqslant \delta .
\end{gathered}
$$

So, $\forall u, v \in H_{B}$ we have

$$
[W u, v]=[\hat{Q} G \hat{Q} u, v]=[G \hat{Q} u, \hat{Q} v]=[\hat{Q} u, G \hat{Q} v]=[u, \hat{Q} G \hat{Q} v]=[u, W v],
$$

So, the operator $W$ is a symmetric.

From inequality (34), $\forall u \in H_{B}$, we have:

$$
[W u, u]=[\hat{Q} G \hat{Q} u, u]=[G \hat{Q} u, \hat{Q} u] \leqslant \delta\|\hat{Q} u\|_{B}^{2} .
$$

Similarly:

$$
[W u, u]=[\hat{Q} G \hat{Q} u, u]=[G \hat{Q} u, \hat{Q} u] \geqslant \gamma\|\hat{Q} u\|_{B}^{2} .
$$

From relationships (53), (54), we can conclude that there exists constant $\sigma$ and $\eta$, for which the condition (52) holds, satisfying the inequality (41).

Taking into account (36), (49), (42), (45), (41), (46) and (40) we get:

$$
\begin{aligned}
S\left(u^{*}-u_{k}\right) & =S\left(u^{*}-\left(u_{k-1}+\tau_{k} v_{k}+w_{k}\right)\right)=S\left(u^{*}-u_{k-1}\right)-\tau_{k} S v_{k}+\tau_{k} \hat{P} S v_{k} \\
= & S\left(u^{*}-u_{k-1}\right)-\tau_{k} \hat{Q} S G\left(u^{*}-u_{k-1}\right)=S\left(u^{*}-u_{k-1}\right)-\tau_{k} \hat{Q} G S\left(u^{*}-u_{k-1}\right) \\
& =\hat{Q} S\left(u^{*}-u_{k-1}\right)-\tau_{k} W S\left(u^{*}-u_{k-1}\right)=\left(\hat{Q}-\tau_{k} W\right) S\left(u^{*}-u_{k-1}\right), \quad k \geqslant 2 .
\end{aligned}
$$


So:

$$
S\left(u^{*}-u_{k}\right)=\left(\hat{Q}-\tau_{k} W\right) S\left(u^{*}-u_{k-1}\right), \quad k \geqslant 2 .
$$

We draw attention to the fact that the quadratic function (35) could be represented as:

$$
F(u)=\left\|S\left(u-u^{*}\right)\right\|_{B}^{2}-\left\|S u^{*}\right\|_{B}^{2}, \quad \forall u \in H_{B},
$$

where $u^{*}$ is the generalized solution of the equation (32).

So we get:

$$
\begin{aligned}
F(u) & =[G u, u]-2[g, u]=[G u-g, u]-[g, u] \\
& =\left[G\left(u-u^{*}\right), u\right]-\left[G u^{*}, u\right]=\left[S\left(u-u^{*}\right), S u\right]-\left[S u^{*}, S u\right] \\
& =\left[S\left(u-u^{*}\right), S u\right]-\left[S u^{*}, S u^{*}\right]+\left[S u^{*}, S u^{*}\right]-\left[S u^{*}, S u\right] \\
& =\left[S\left(u-u^{*}\right), S u\right]-\left[S u^{*}, S\left(u-u^{*}\right)\right]-\left\|S u^{*}\right\|_{B}^{2} \\
& =\left\|S\left(u-u^{*}\right)\right\|_{B}^{2}-\left\|S u^{*}\right\|_{B}^{2} .
\end{aligned}
$$

From (53) it follows:

$$
\left\|S\left(u^{*}-u_{k}\right)\right\|_{B}^{2} \leqslant\left\|(\hat{Q}-\tau W) S\left(u^{*}-u_{k-1}\right)\right\|_{B}^{2}, \quad k \geqslant 2, \quad \forall \tau \in \mathbb{R} .
$$

From (55), we get:

$$
\begin{aligned}
\left\|S\left(u^{*}-u_{k}\right)\right\|_{B}^{2} & \leqslant\left\|(\hat{Q}-\tau W) S\left(u^{*}-u_{k-1}\right)\right\|_{B}^{2} \\
& \leqslant\|(\hat{Q}-\tau W)\|_{B}^{2(k-1)}\left\|S\left(u^{*}-u_{1}\right)\right\|_{B}^{2}, \quad k \geqslant 2, \quad \forall \tau \in R .
\end{aligned}
$$

The numeric parameter $\tau$ is chosen so that the operator $\hat{Q}-\tau W$ has the lowest possible norm. As the spectrum of a linear operator $W$ lies on the segment $[\sigma, \eta]$, so the operator's norm $\hat{Q}-\tau W$ is minimal if:

$$
\tau=\frac{2}{\eta+\sigma} .
$$

and:

$$
q=\|\hat{Q}-\tau W\|_{B}=\frac{\eta-\sigma}{\eta+\sigma} .
$$

In addition we got an estimation:

$$
\left\|S\left(u^{*}-u_{k}\right)\right\| \leqslant q^{k-1}\left\|S\left(u^{*}-u_{1}\right)\right\|_{B}, \quad k \geqslant 2, \quad \forall \tau \in \mathbb{R} .
$$

From the definition of the projection operator $\hat{Q}$ and from the formulas (51), (50), $\forall u \in \hat{H}^{\perp}$ it follows:

$$
\sigma\|u\|_{B}^{2} \leqslant[W u, u]=\left[\hat{Q} S^{2} \hat{Q} u, u\right]=[S \hat{Q} u, S \hat{Q} u]=[S u, S u]=\|S u\|_{B}^{2} .
$$

Similarly from (34) and an operator definition $Q$ :

$$
\begin{aligned}
\forall u \in \hat{H}_{B}:[\hat{Q} S Q u, \hat{Q} S Q u] & =[Q u, S \hat{Q} S Q u] \\
& =\left[Q u, S^{2} Q u\right]=[G Q u, Q u] \leqslant \delta\|Q u\|_{B}^{2}, \\
{[W u, u]=\left[\hat{Q} S^{2} \hat{Q} u, u\right] } & =[S \hat{Q} u, S \hat{Q} u]=\|S \hat{Q} u\|_{B}^{2} \leqslant \eta\|u\|_{B}^{2} .
\end{aligned}
$$

We can conclude that there exists $\eta$ such that holds an inequality $\|\hat{Q} S Q u\|_{B}^{2} \leqslant \eta\|Q u\|_{B}^{2}$. 
An estimate (26) we get from the formulas (34), (41), (56), (46), (58) and (39):

$$
\begin{aligned}
\left\|u^{*}-u_{k}\right\|_{B}^{2} & \leqslant \frac{1}{\gamma}\left[G\left(u^{*}-u_{k}\right), u^{*}-u_{k}\right]=\frac{1}{\gamma}\left\|S\left(u^{*}-u_{k}\right)\right\|_{B}^{2} \leqslant \frac{1}{\gamma} q^{2(k-1)}\left\|S\left(u^{*}-u_{k}\right)\right\|_{B}^{2} \\
& =\frac{1}{\gamma} q^{2(k-1)}\left\|\hat{Q} S\left(u^{*}-u_{1}\right)\right\|_{B}^{2} \leqslant \frac{\eta}{\gamma} q^{2(k-1)}\left\|u^{*}-u_{1}\right\|_{B}^{2}, \quad k \geqslant 2 .
\end{aligned}
$$

To get estimate (27), we have to take into account relationships (34), (41), (46), (57), (39), (45), (31):

$$
\begin{aligned}
\left\|u^{*}-u_{k}\right\|_{B}^{2} & \leqslant \frac{1}{\gamma}\left[G\left(u^{*}-u_{k}\right), u^{*}-u_{k}\right]=\frac{1}{\gamma}\left\|S\left(u^{*}-u_{k}\right)\right\|_{B}^{2} \leqslant \frac{1}{\sigma \gamma}\left\|G\left(u^{*}-u_{k}\right)\right\|_{B}^{2}= \\
& =\frac{1}{\sigma \gamma}\left\|g-G u_{k}\right\|_{B}^{2} \leqslant \frac{1}{\sigma \gamma}\left\|B^{-1}\left(f-A u_{k}\right)\right\|_{B}^{2}, \quad k \geqslant 2 .
\end{aligned}
$$

From the estimates (25), (26) it is clear that the variation-gradient method converges better than gradient-type methods. In the case $B=K=I$ and the operator $A$ is bounded, positive-definite, symmetric then the method (10)-(17) degenerates into an ordinary variation gradient method for a positive-definite, bounded, and symmetric operator [15].

\section{Numerical experiment}

The issue of research the tasks of controlling unmanned aerial vehicles and constructing the optimal flight path is given a lot of attention $[2,6,13,16,17,22]$. Since unmanned aerial vehicles become more autonomous, critical and complex systems require prior forecasting and analysis to minimize costs. The development of technologies entails an increase in the complexity of control objects, an increase in the quality requirements and the accuracy of control due to the increase in the cost of control error. This makes further development and improvement of methods that solve the problem of optimal control of unmanned aerial vehicles. Therefore, their development and application to the problems of analysis of models of automated control systems of unmanned aerial vehicles is a relevant and perspective task.

The dynamical model of control of a light unmanned aerial vehicle of mass $m$ was considered. Its motion is described by a system of three ordinary differential equations of the first order. With the appropriate choice of control forces $\left(F_{r}, F_{\varphi}\right)$, equations of this type describe the flat motion of an aircraft in phase variables $(r, \dot{r}, \dot{\varphi})$, where $(r, \varphi)$ is the output polar coordinate system. Under these conditions, the integro-differential model of the aircraft movement is described by the equations:

$$
\left\{\begin{array}{l}
m\left(\ddot{r}-r \dot{\varphi}^{2}\right)=F_{r} \\
m(r \ddot{\varphi}+2 \dot{r} \dot{\varphi})=F_{\varphi}
\end{array}\right.
$$

Let the governing forces be:

$$
\begin{aligned}
& F_{r}=m\left[\mu_{2}^{2} r^{2}-r \dot{\varphi}^{2}-\left(\mu_{1}+\mu_{2}\right)\left(\dot{r}+\mu_{2} r\right)+g(\dot{\varphi})\right], \\
& F_{\varphi}=m\left[\left(2 \dot{r}-\mu_{3} r\right) \dot{\varphi}+r^{2}\right]
\end{aligned}
$$

here $\mu_{1}, \mu_{2}, \mu_{3}$ are constants and $g(\dot{\varphi})$ is a governing function. Then performing the replacement of variables:

$$
\begin{aligned}
& x_{1}=\dot{r}+\mu_{2} r, \\
& x_{2}=r, \\
& x_{3}=\dot{\varphi},
\end{aligned}
$$

Mathematical Modeling and Computing, Vol. 6, No. 2, pp. 344-357 (2019) 
the initial equations of the trajectory of motion of an unmanned aircraft can be written in the form of a three-dimensional system:

$$
\left\{\begin{array}{l}
\dot{x}_{1}=-\mu_{1} x_{1}+g\left(x_{3}\right) \\
\dot{x}_{2}=-\mu_{2} x_{2}+x_{1} \\
\dot{x}_{3}=-\mu_{3} x_{3}+x_{2}
\end{array}\right.
$$

which is the main object of research. The obtained system of equations is reduced to the ordinary differential equation of the third order:

$$
y^{\prime \prime \prime}+\left(\mu_{1}+\mu_{2}+\mu_{3}\right) y^{\prime \prime}+\left(\mu_{1} \mu_{2}+\mu_{1} \mu_{3}+\mu_{2} \mu_{3}\right) y^{\prime}+\mu_{1} \mu_{2} \mu_{3} y=g(y)
$$

with unknown variable $y(t)=x_{3}(t)$.

We will conduct a comparative experiment in order to demonstrate the real possibilities of the variation-gradient method in comparison with the gradient method in the research of the integrodifferential model of the motion of an unmanned machine (59), (60).

To do this, consider the problem of remote control of a lightweight aircraft, which is described by the system (59) and the control forces:

$$
\begin{aligned}
& F_{r}=m\left[5 r^{2}-r \dot{\varphi}^{2}+56-24 t^{2}-4 \int_{0}^{1} G(t, \xi) \dot{\varphi}(\xi) d \xi\right], \\
& F_{\varphi}=m\left[2 \dot{r} \dot{\varphi}+r^{2}\right] .
\end{aligned}
$$

The core of the integral part of the equation has the form:

$$
G(t, \xi)= \begin{cases}\xi, & 0 \leqslant \xi \leqslant t \\ \xi-1, & t \leqslant \xi \leqslant 1 .\end{cases}
$$

Under conditions $\dot{\varphi}(0)=\dot{\varphi}(1)=(1)=0$. According to (61) and (59), (62) we get a problem:

$$
\left\{\begin{array}{l}
y^{\prime \prime \prime}(t)-5 y^{\prime}(t)+4 \int_{0}^{1} G(t, \xi) y(\xi) d \xi=56-24 t^{2} \\
y(0)=y(1)=y^{\prime \prime}(1)=0 .
\end{array}\right.
$$

In the course of the experiment, the steepest descent method (gradient method) and variationalgradient methods for the integro-differential model (64), (63) with a $K$-positive-definite $K$-symmetric operator were used to build the trajectory of the unmanned aircraft.

The problem (64), (63) satisfies the conditions of the theorem on the convergence of the variationgradient method for equations with $K$-positive-definite $K$-symmetric operators if

$$
\begin{gathered}
K y(t)=\int_{0}^{t} y(\xi) d \xi \\
\left\{\begin{array}{l}
B y(t)=y^{\prime \prime \prime} \\
y(0)=y(1)=y^{\prime \prime}(1)=0 .
\end{array}\right.
\end{gathered}
$$

So the system (59), (64), (63) describing the integro-differential model of motion of the apparatus has a unique solution, as well as methods of the steepest descent and the variation-gradient method for this task converge.

For the equation (64), (63) the exact solution can be obtained analytically:

$$
\dot{\varphi}=y(t)=-0.2529233637 e^{2 t}+4.3030627419 e^{t}+11.6969372581 e^{-t}-15.7470766363 e^{-2 t}-12 t,
$$


which is depicted in Fig. 1.

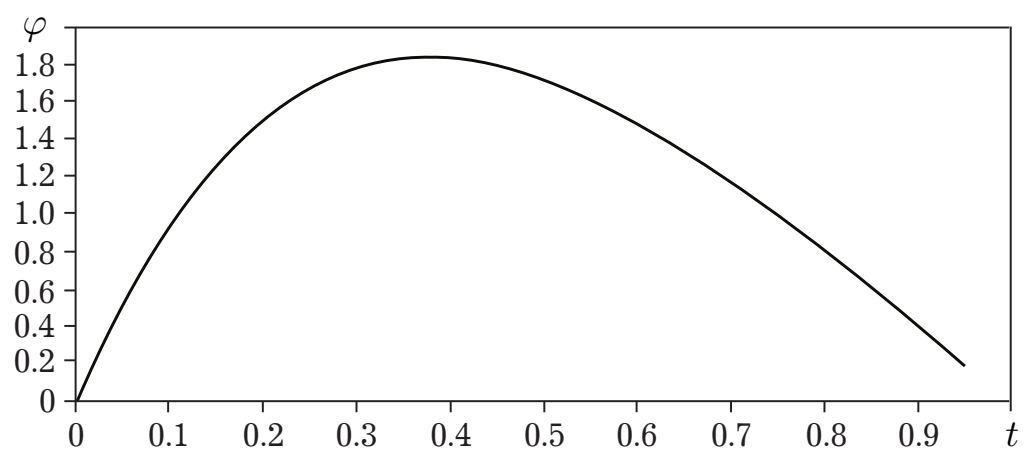

Fig. 1. A graph of the exact solution of the differential equation - the rate of change of the angle of rotation of the UAV.

From the equation of change, using found $\dot{\varphi}$, the desired flight path of an unmanned aircraft was found, which corresponds to the flight task and has the form (Fig. 2):

$$
\begin{aligned}
x= & \left(-0.5058 e^{2 t}+4.3031 e^{t}-11.6969 e^{-t}+31.4942 e^{-2 t}-12\right) \\
& \times \cos \left(-0.12645 e^{2 t}+4.3031 e^{t}-11.6969 e^{-t}+7.87355 e^{-2 t}-6 t^{2}\right) ; \\
y= & \left(-0.5058 e^{2 t}+4.3031 e^{t}-11.6969 e^{-t}+31.4942 e^{-2 t}-12\right) \\
& \times \sin \left(-0.12645 e^{2 t}+4.3031 e^{t}-11.6969 e^{-t}+7.87355 e^{-2 t}-6 t^{2}\right) ;
\end{aligned}
$$

For the implementation of the steepest descent method and the variational-gradient method, computation a mathematical package Derive A Mathematical Assistant was used.

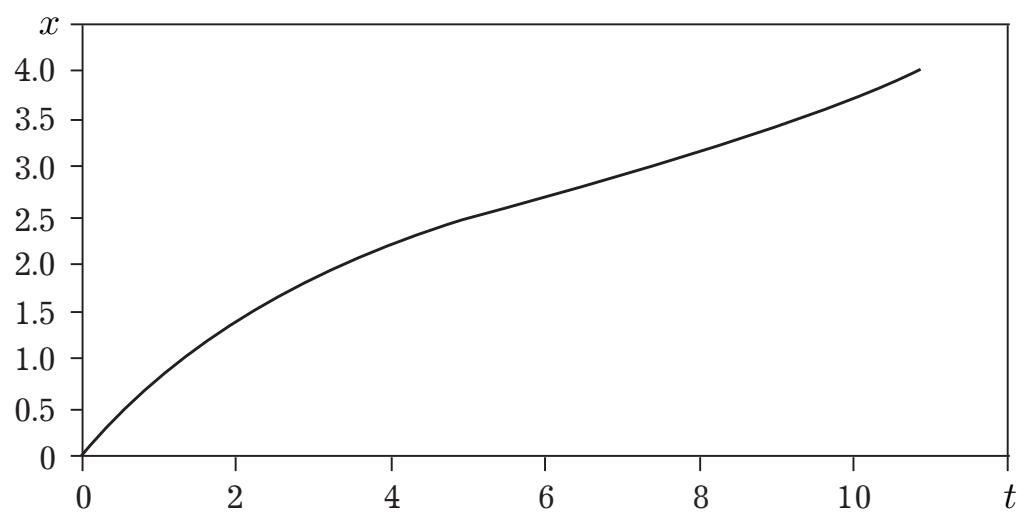

Fig. 2. Trajectory of UAV.

As the coordinate functions the sequence $\left\{\varphi_{i}(t)=t^{i}(t-1)^{3}\right\}_{i \geqslant 1} \subset H_{0}$ was considered. To build an approximations $n=2$ was proposed that is two coordinate functions were considered $\varphi_{1}(t)=t(t-1)^{3}$ and $\varphi_{2}(t)=t^{2}(t-1)^{3}$, as an arbitrary function for the initial approximation $y_{0}=t(t-1)^{3}$ was taken which satisfies the initial conditions.

The results are below in Tables 1,2.

When solving this problem by the variation gradient method, after the first iteration, we obtained an solution of problems with accuracy $\varepsilon=10^{-4}$. To obtain such accuracy with the gradient method, we needed to make four iterations. 
Table 1. The method of the steepest descent.

\begin{tabular}{|c|c|c|c|c|}
\hline$y$ & $\left|y^{*}-y_{1}\right|$ & $\left|y^{*}-y_{2}\right|$ & $\left|y^{*}-y_{3}\right|$ & $\left|y^{*}-y_{4}\right|$ \\
\hline 0 & 0 & 0 & 0 & 0 \\
0.25 & 0.0691565 & 0.017482 & $2.77067 \cdot 10^{-4}$ & $3.26538 \cdot 10^{-4}$ \\
0.5 & 0.089972 & 0.018708 & 0.00185044 & $4.352977 \cdot 10^{-4}$ \\
0.75 & 0.1194197 & 0.014608 & $8.49059 \cdot 10^{-4}$ & $3.5819054 \cdot 10^{-4}$ \\
1 & 0 & 0 & 0 & 0 \\
\hline
\end{tabular}

Table 2. Variation gradient method.

\begin{tabular}{|c|c|c|c|}
\hline$y$ & $\left|y^{*}-y_{1}\right|$ & $\left|y^{*}-y_{2}\right|$ & $\left|y^{*}-y_{3}\right|$ \\
\hline 0 & 0 & 0 & 0 \\
0.25 & $8.688108 \cdot 10^{-4}$ & $5.94684 \cdot 10^{-7}$ & $9.920092 \cdot 10^{8}$ \\
0.5 & $8.284705 \cdot 10^{-4}$ & $1.6588193 \cdot 10^{-6}$ & $6.572201 \cdot 10^{-7}$ \\
0.75 & $4.087585 \cdot 10^{-4}$ & $9.157572 \cdot 10^{-6}$ & $1.402053 \cdot 10^{-6}$ \\
1 & 0 & 0 & 0 \\
\hline
\end{tabular}

The conducted experiment showed that the finding of the solution by the variation-gradient method allows reducing arithmetic calculations by at least $60 \%$ in comparison with the method of the steepest descent.

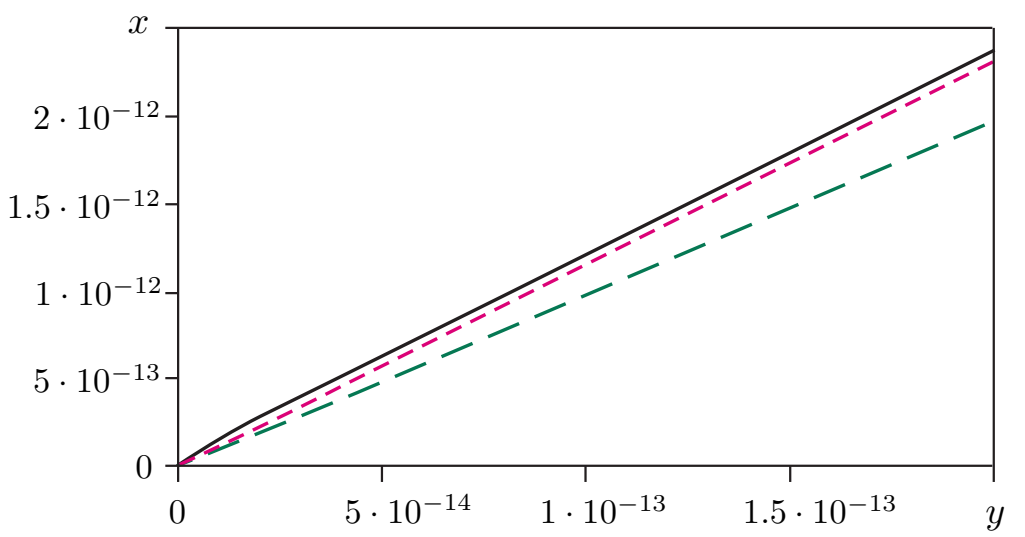

Fig. 3. The graph of the first approximations. 1) Exact solution (—

2) The first approximation with VGM (--------); 3) The first approximation with MFD (- - - $)$.

Graphs of the first approximations on the segment were constructed to visualize the effectiveness of the variation gradient method $\left[0 ; 2.5 \cdot 10^{-13}\right]$ (Fig. 3). In the chart, the blue color shows the exact solution, the red first approximation is constructed according to the variation gradient method, and the green one is an approximation constructed by the method of the steepest descent.

At the same time, it should be noted that in practice it is not always possible to construct an adequate model in a linear analytical form. This complicates the use of variation gradient. Therefore, the further development of the theory of variational-gradient methods consists in the extension of these methods to broader classes of models.

\section{Conclusion}

According to the estimates obtained in the theorem, the variation-gradient method has a high convergence rate, is resistant to disturbances and does not require knowledge of the boundaries of the spectrum of the integro-differential operator. Therefore, the research of an integro-differentia model using the variation-gradient method for a $K$-positive-definite, $K$-symmetric operator will increase the 
efficiency of information processing in the processes of control and research of dynamic systems. Application of the variation-gradient method to the control tasks will allow extending the range of problems considered.

[1] Barabash O. V., Dakhno N. B., Shevchenko H. V., Neshcheret O. S., Musienko A. P. Information Technology of Targeting: Optimization of Decision Making Process in a Competitive Environment. International Journal of Intelligent Systems and Applications. 9 (12), 1-9 (2017).

[2] Mashkov O. A., Al-Tameemi Raheem Qasim Naser, Lami Juhi Hussein, Kosenko V. R. Application informal approach to contriol complex dynamic systems. Control, navigation and communication systems. 4, 31-37 (2015), (in Ukrainian).

[3] Kucherov D. P. On some methods and algorithms for calculating matrix exponential in problems of control system dynamics analysis. Upravlyayushchie Sistemy i Mashiny. 11-17 (2001), (in Russian).

[4] Chakraborty A., Konar A. Mathematical Modeling and Analysis of Dynamical Systems. In: Emotional Intelligence. Studies in Computational Intelligence. Vol. 234. Berlin, Heidelberg, Springer (2009).

[5] Barabash O., Kravchenko Y., Mukhin V., Kornaga Y., Leshchenko O. Optimization of Parameters at SDN Technologie Networks. International Journal of Intelligent Systems and Applications. 9 (9), 1-9 (2017).

[6] Gramajo G., Shankar P. An Efficient Energy Constraint Based UAV Path Planning for Search and Coverage. International Journal of Aerospace Engineering. 2017, Article ID 8085623, 13 pages (2017).

[7] Mashkov O. A., Mamchur Yu. V. Analytical estimation of the quality of the control process on the simulators of a remote pilot airplane with algorithm based on the solution of the reverse dynamics problems. Aerospace technologies. 2, 59-62 (2017).

[8] Obidin D., Ardelyan V., Lukova-Chuiko N., Musienko A. Estimation of functional stability of special purpose networks located on vehicles. 2017 IEEE 4th International Conference Actual Problems of Unmanned Aerial Vehicles Developments (APUAVD), Kiev. 167-170 (2017).

[9] Barabash O., Lukova-Chuiko N.,Sobchuk V., Musienko A. Application of Petri Networks for Support of Functional Stability of Information Systems. 2018 IEEE 1st International Conference on System Analysis and Intelligent Computing, SAIC 2018 - Proceedings. Kiev. 167-170 (2017).

[10] Boichuk O., Holovats'ka I. Boundary-Value Problems for Systems of Integrodifferential Equations. Journal of Mathematical Sciences. 203 (3), 306-321 (2014).

[11] Perestyuk M. O., Kasyanov P. O., Zadoyanchuk N. V. On Faedo-Galerkin method for evolution inclusions with $W_{\lambda_{0}}$-pseudomonotone maps. Memoirs on Differential Equations and Mathematical Physics. 44, 105-132 (2008).

[12] Tuyrin V., Barabash O., Openko P., Sachuk I., Dudush A. Informational support system for technical state control of military equipment. 2017 IEEE 4th International Conference Actual Problems of Unmanned Aerial Vehicles Developments (APUAVD), Kiev. 230-232 (2017).

[13] Kucherov D., Kozub A. Model of UAV as agent of multiagent system. 2018 IEEE 9th International Conference on Dependable Systems, Services and Technologies (DESSERT), Kiev. 343-347 (2018).

[14] Kucherov D., Kozub A. Rasstrygin A. Setting the PID Controller for Controlling Quadrotor Flight: a Gradient Approach. 2018 IEEE 5th International Conference on Methods and Systems of Navigation and Motion Control, MSNMC. 90-93 (2018).

[15] Luchka A. Yu., Noschenko O. E., Tuhalevskaya N. I. Variational Gradient Method. USSR Computational Mathematics and Mathematical Physics. 24 (4), 1-6 (1984).

[16] Barabash O., Dakhno N., Shevchenko H., Sobchuk V. Integro-Differential Models of Decision Support Systems for Controlling Unmanned Aerial Vehicles on the Basis of Modified Gradient Method. 2018 IEEE 1st International Conference on System Analysis and Intelligent Computing, SAIC, 94-97 2018.

[17] Barabash O. V., Dakhno N. B., Shevchenko H. V., Majsak T. V. Dynamic models of decision support systems for controlling UAV by two-step variational-gradient method. 2017 IEEE 4th International Conference on Actual Problems of Unmanned Aerial Vehicles Developments, APUAVD. 108-111 (2017).

[18] Petryshyn W.V. On a class of K-p.d. and non-K-p.d. operators and operator equations. Journal of Matheamatical analysis and applications. 10 (1), 1-24 (1965).

Mathematical Modeling and Computing, Vol. 6, No. 2, pp. 344-357 (2019) 
[19] Lutsenko A. V., Skorik V. A. Funkcija Grina i ee primenenie. Har'kov, Har'kovskij nacional'nyj universitet im. V.N. Karazina (2002), (in Russian).

[20] Kadets V. A Course in Functional Analysis and Measure Theory. Springer, Cham (2018).

[21] Lenkov S. V., Khoroshko V. O., Dakhno N. B. Odnokrokovyi variatsiino-hradiientnyi metod shchodo matematychnykh modelei kompleksnykh system zakhystu informatsii. Visnyk Kyivskoho natsionalnoho universytetu imeni Tarasa Shevchenka. Viiskovo-spetsialni nauky. 22, 10-13 (2009), (in Ukrainian).

[22] Mashkov O. A., Durniak B. V., Mamchur Yu. V., Timchenko O. V. Syntez alhorytmu prohramnoho keruvannia na trenazheri dystantsiino pilotovanoho litalnoho aparata na osnovi alhorytmichnoi protsedury rishennia zvorotnoi zadachi dynamiky (stokhastychna postanovka). Modeliuvannia ta informatsiini tekhnolohii. 82, 166-176 (2018), (in Ukrainian).

\title{
Удосконалення варіаційно-градієнтного методу в динамічних системах автоматизованого управління інтегро-диференційними моделями
}

\author{
Машков О. А. ${ }^{1}$, Собчук В. В. ${ }^{2}$, Барабаш О. В. ${ }^{3}$, Дахно Н. Б. ${ }^{3}$, Шевченко Г. В. ${ }^{3}$, Майсак Т. В. \\ ${ }^{1}$ Держсавна екологічна академія післядипломної освіти та менеджменту, \\ вул. Василя Липківсъкого, 35, корп. 2, Київ, 03035, Украӥна \\ ${ }^{2}$ Східноєвропейсъкий начіональний університет імені Лесі Украӥнки, \\ вул. Потапова, 9, Луивк, 43000, Украӥна \\ ${ }^{3}$ Державний університет телекомунікацій, \\ вул. Солом'янська, 7, Київ, 03110, Украӥна \\ ${ }^{4}$ Київсъкий національний економічний університет імені Вадима Гетвмана, \\ проспект Перемоги, 54/1, Київ, 03057, Україна
}

\begin{abstract}
Розглянуто динамічні системи, що задані інтегро-дифереційними моделями з $K$-симетричним $K$-позитивно визначеним оператором. До зазначених моделей застосовано варіаційно-градієнтний метод. Проведений аналіз показав, що для реалізації цього методу не потрібно знання спектра оператора, крім того, у нього вища швидкість збіжності та стійкість до збурень порівняно з градієнтними методами. В роботі доведено теорему, яка дає змогу зробити висновки про ефективність застосування варіаційно-градієнтного методу для дослідження завдань управління. Дослідження інтегро-диференційної моделі з $K$-позитивно визначеним $K$-симетричним оператором за допомогою варіаційно-градієнтного методу дозволить підвищити оперативність опрацювання інформації в процесах управління і дослідження динамічних систем. Застосування варіаційно-градієнтного методу до задач управління розширить коло задач, що розглядаються. Оскільки розвиток сучасних технологій спричинює зростання складності об'єктів управління, підвищення вимог до якості й точності управління внаслідок зростання ціни управлінської помилки, необхідні подальший розвиток та удосконалення методів, які вирішують завдання оптимального управління, наприклад, безпілотними літальними апаратами. На модельному прикладі розглянуто застосування варіаційно-градієнтного методу до моделей систем автоматизованого управління безпілотними літальними апаратами.
\end{abstract}

Ключові слова: автоматизоване управління, варіаційно-градієнтний метод, динамічні системи, інтегро-диференційні моделі, оптимізачія управління.

2000 MSC: $34 \mathrm{~K} 28$

удк: 517.977 